\title{
Meiotic Studies in Himalayan Celastraceae and Rhamnaceae
}

\author{
T.S. Sareen, P.K. Khosla and P.N. Mehra \\ Department of Botany, Panjab University, Chandigarh, India
}

Received November 25, 1972

The family Celastraceae embraces 850 species belonging to 55 woody genera with wide distribution except in the arctic. About 70 species and 12 genera are met in India. Two of these, Lophopetalum fimbriatum from Eastern Himalayas and $L$. wightianum from South India, yield commercial timber. Several species of Euonymus are ornamental.

Rhamnaceae is a family of 58 genera and 900 species distributed in the tropical and temperate regions. Ten genera with roughly 40 species occur in India. Zizyphus jujuba and $Z$. xylopyrus yield low grade timber. Jujube is one of the most common wild fruit trees in India.

This study was part of the wider project "Cytomorphological Investigations of Himalayan Hardwoods" undertaken by us from 1962-1967. The chromosome counts of newly studied species have been published in IOPB chromosome numbers reports (Mehra and Khosla 1969, Mehra and Sareen 1969).

Table 1. Source of the material

\begin{tabular}{|c|c|}
\hline $\begin{array}{l}\text { Principal station with } \\
\text { latitude and longitude }\end{array}$ & $\begin{array}{l}\text { Specific locality with } \\
\text { altitude in meters }\end{array}$ \\
\hline $\begin{array}{c}\text { Eastern Himalayas: } \\
\text { Darjeeling } \quad \begin{array}{l}\left(27^{\circ} 30^{\prime} \mathrm{N}\right. \\
\left.88^{\circ} 18^{\prime} \mathrm{E}\right)\end{array}\end{array}$ & $\begin{array}{l}\text { 1) Jalapahar 2300; 2) Senchal 2100; } \\
\text { 3) Sukna } 150 .\end{array}$ \\
\hline 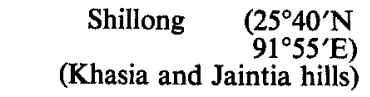 & $\begin{array}{l}\text { 4) Elephant falls } 1800 \text {; 5) Garampani } 760 \text {; } \\
\text { 6) Lake garden } 1500 ; \text { 7) Shillong } 1500 \text {; } \\
\text { 8) Shillong peak } 1800 \text {. }\end{array}$ \\
\hline $\begin{array}{r}\text { Western Himalayas: } \\
\text { Nainital } \quad \begin{array}{r}\left(29^{\circ} 22^{\prime} \mathrm{N}\right. \\
\left.79^{\circ} 29^{\prime} \mathrm{E}\right)\end{array}\end{array}$ & $\begin{array}{l}\text { 9) Enroute Cheena peak } 1950 ; 10 \text { ) Kapkote } 1100 \text {; } \\
\text { 11) Lalkuan } 350 ; 12 \text { ) Guma } 1200 ; \\
\text { 13) Kandaghat } 1700 ; \text { 14) Kufri } 2600 ; \\
\text { 15) Mahasu peak 2650; 16) Narkanda 2700; } \\
\text { 17) Taradevi 1800; 18) Tatapani } 760 .\end{array}$ \\
\hline
\end{tabular}

Material and methods

The material for meiotic studies was collected from wild populations in the Himalayas. The flower buds were fixed in Carnoy's fluid. After one or two days anther squashes were prepared in $1.0 \%$ aceto-carmine. The photomicrographs as also the camera lucida drawings are at a uniform magnification of $\times 1360$. The voucher specimens have been kept in the Herbarium of the Botany Department of Panjab University. 
Results and discussion

The results of cytological studies on 21 species are summarized in Table 2. The genera and species under each family are arranged according to their timber/ forestry importance. The specific localities of voucher specimens are designated by figures as given in Table 1. Meiosis was observed to be normal in all species.

Celastraceae: Lophopetalum fimbriatum is a lofty tree of Sikkim Terai. PMC's at diakinesis showed 20 bivalents which were well spread (Fig. 4). This is the first chromosomal determination in the genus and is suggestive of 20 as its basic number.

The genus Elaeodendron has not been investigated cytologically before. $E$. roxburghii showed a haploid number $\mathrm{n}=17$ (Fig. 5) which may be considered as basic number of the genus.

Seven species of Euonymus have been cytologically studied for the first time. E. echinatus revealed the lowest chromosome number, $\mathrm{n}=8$, (Fig. 2) in the genus,

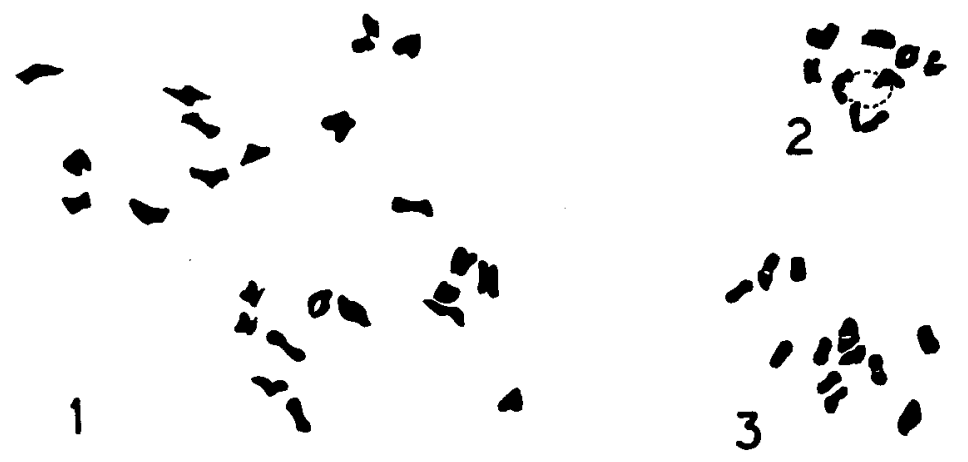

Figs. 1-3. 1, Euonymus bullatus: $\mathrm{n}=24$, metaphase I. 2, E. echinatus: $\mathrm{n}=\mathbf{8}$, diakinesis. 3, Berchemia floribunda: $\mathrm{n}=12$, metaphase $\mathrm{I}$.

thereby, establishing its basic number $\mathrm{x}=8$ as earlier suggested by Darlington and Wylie (1955). E. echinatus is diploid, E. bullatus hexaploid (Fig. 1) while E. grandi* florus, E. lacerus, E. frigidus, E. pendulus and E. hamiltonianus are tetraploids. Euonymus is one of the few tree genera which are rich in incidence of polyploidy.

Celastrus paniculatus with $\mathrm{n}=23$ substantiates earlier report by Adatia and Bavade (1962).

Gymnosporia acuminata (Fig. 6) and G. rufa, each with $\mathrm{n}=18$, have not been earlier worked out cytologically.

The presently investigated five genera of Celastraceae display different basic numbers: Lophopetalum $(\mathrm{x}=20)$, Elaeodendron $(\mathrm{x}=17)$, Euonymus $(\mathrm{x}=8)$, Celastrus $(\mathrm{x}=23)$ and Gymnosporia $(\mathrm{x}=18)$. Evidently, aneuploidy has played signifcant role in generic differentiation of the family.

Rhamnaceae: Zizyphus jujuba is a morphologically variable species widely distributed in dry forests of India, also cultivated for its fruit. Our observations on materials collected from four wild populations consistently revealed $n=24$. 
Previous chromosome counts in this species are $n=12,20,24,36$ and $2 n=60,96$ (see Table 2). Thus, diploid, tetraploid, pentaploid, hexaploid and octaploid races based on $\mathrm{x}=12$ exist in this species. In $Z$. xylopyrus, PMC's at diakinesis

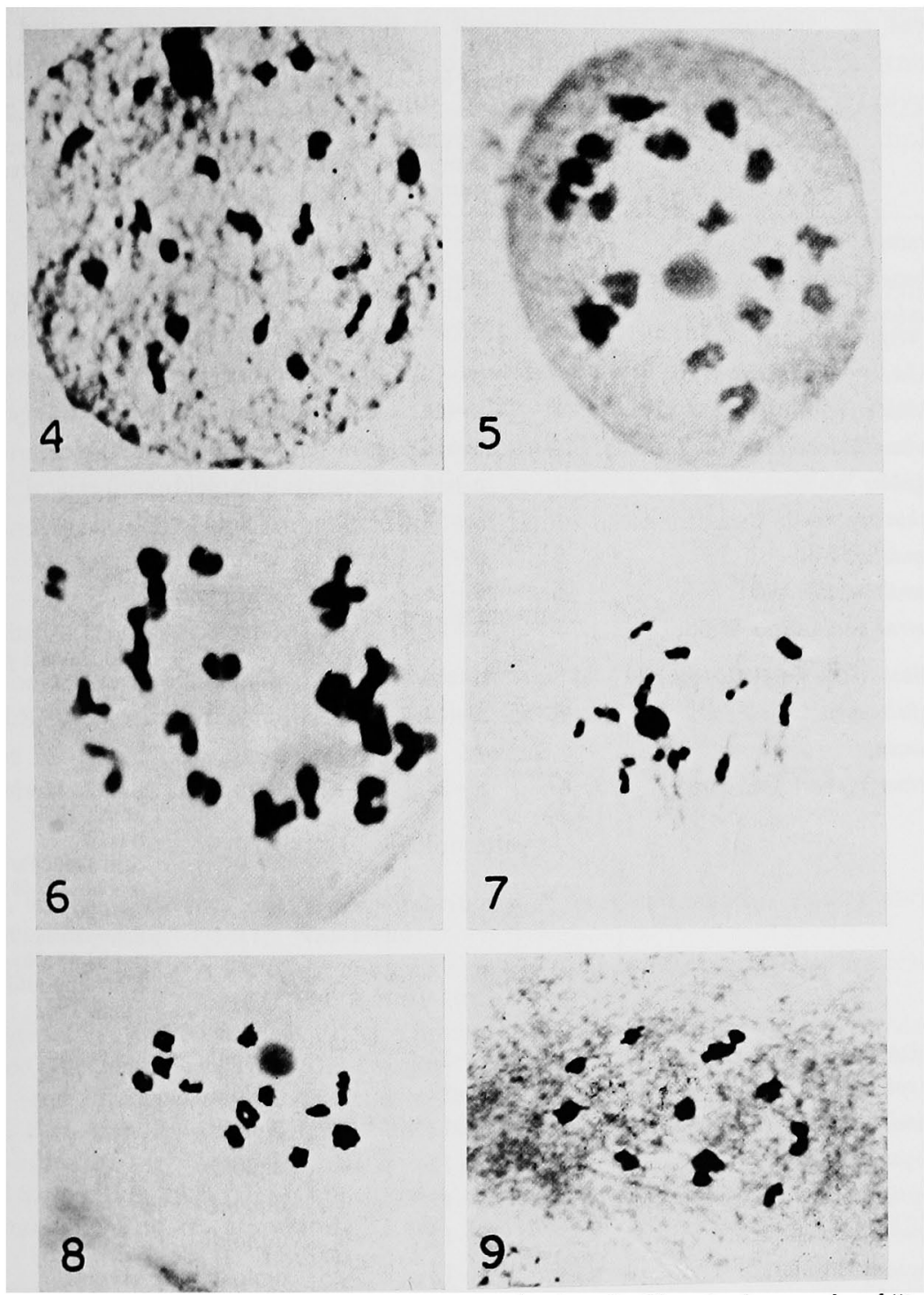

Figs. 4-9. 4, Lophopetalum fimbriatum: $\mathrm{n}=20$, diakinesis. 5, Elaeodendron roxburghii: $\mathrm{n}=17$, diakinesis. 6, Gymnosporia acuminata: $\mathrm{n}=18$, metaphase I. 7, Zizyphus xylopyrus: $\mathrm{n}=12$, diakinesis. 8, Z. oxyphylla: $\mathrm{n}=12$, diakinesis. 9, Sageretia hamosa: $\mathrm{n}=12$, metaphase $\mathrm{I}$.

showed 12 bivalents and a nucleolus with one bivalent showing early disjunction. Almost all bivalents appeared rod-shaped (Fig. 7). Likewise, $Z$. oxyphylla revealed 12 bivalents along with a nucleolus at diakinesis. The bivalents were of rod and 
ring type (Fig. 8). No previous chromosome record is available for these two species.

Rhamnus triqueter and $R$. purpureus, each having $\mathrm{n}=12$, are being reported here for the first time.

Table 2. Chromosome numbers in Celastraceae and Rhamnaceae

\begin{tabular}{|c|c|c|c|c|c|}
\hline Taxon & Locality & $\begin{array}{l}\text { Chromo- } \\
\text { some } \\
\text { number }\end{array}$ & $\begin{array}{l}\text { Fig. } \\
\text { no. }\end{array}$ & $\begin{array}{l}\text { Presumed } \\
\text { level of } \\
\text { ploidy }\end{array}$ & Previous reports \\
\hline \multicolumn{6}{|l|}{ Celastraceae } \\
\hline Lophopetalum fimbriatum Wight & 3 & $n=20$ & 4 & diploid & \\
\hline $\begin{array}{l}\text { Elaeodendron roxburghii } \\
\text { Wight and Arn. }\end{array}$ & 3 & $\mathrm{n}=17$ & 5 & diploid & \\
\hline Euonymus grandiflorus Wall. & 4 & $n=16$ & - & tetraploid & \\
\hline E. bullatus Wall. & 8 & $\mathrm{n}=24$ & 1 & hexaploid & \\
\hline E. lacerus Buch-Ham. & 14 & $\mathrm{n}=16$ & - & tetraploid & \\
\hline E. frigidus Wall. & 1 & $\mathrm{n}=16$ & - & tetraploid & \\
\hline E. echinatus Wall. & 1 & $n=8$ & 2 & diploid & \\
\hline E. pendulus Wall. & 9 & $\mathrm{n}=16$ & - & tetraploid & \\
\hline E. hamiltonianus Wall. & 16 & $\mathrm{n}=16$ & - & tetraploid & \\
\hline Celastrus paniculatus Willd. & 5 & $\mathrm{n}=23$ & - & diploid & $\begin{array}{l}\mathrm{n}=23: \text { Adatia } \\
\text { and Bavade } 1962\end{array}$ \\
\hline Gymnosporia acuminata Hook.f. & 8 & $\mathrm{n}=18$ & 6 & diploid & \\
\hline G. rufa Laws. & 6 & $\mathrm{n}=18$ & - & diploid & \\
\hline \multicolumn{6}{|l|}{ Rhamnaceae } \\
\hline Zizyphus jujuba Lam. & $\begin{array}{l}3,10 \\
12,18\end{array}$ & $n=24$ & - & tetraploid & $\begin{array}{l}\mathrm{n}=12 \text { : Morinaga } \\
\text { et al., } 1929 \\
\mathrm{n}=20 \text { : } \\
\text { Srinivasachar } 1940 \\
\mathrm{n}=24,36,48 ; \\
2 \mathrm{n}=96: \\
\text { Srinivasan } 1952 \\
\mathrm{n}=24,48 ; 2 \mathrm{n}=60,96 \\
\text { Khoshoo and } \\
\text { Singh } 1963\end{array}$ \\
\hline Z. xylopyrus Willd. & 11 & $\mathrm{n}=12$ & 7 & diploid & \\
\hline Z. oxyphylla Edgew. & 18 & $\mathrm{n}=12$ & 8 & diploid & \\
\hline Rhamnus triqueter Wall. & 17 & $\mathrm{n}=12$ & - & diploid & \\
\hline R. purpureus Edgew. & 15 & $\mathrm{n}=12$ & - & diploid & \\
\hline Sageretia hamosa Brongn. & 7 & $\mathrm{n}=12$ & 9 & diploid & \\
\hline S. oppositifolia Brongn. & 12 & $\mathrm{n}=12$ & - & diploid & \\
\hline S. theezans Brongn. & 13 & $\mathrm{n}=12$ & - & diploid & $\begin{array}{l}\text { 2n=24: } \\
\text { Bowden } 1945\end{array}$ \\
\hline Berchemia floribunda Wall. & 2 & $n=12$ & 3 & diploid & \\
\hline
\end{tabular}

Sageretia hamosa (Fig. 9), S. oppositifolia and S. theezans displayed uniformity in haploid chromosome number $(n=12)$. The former two species are chromosomally reported for the first time, while the latter confirms the chromosome number reported earlier by Bowden (1945). 
Berchemia floribunda with gametic number 12 (Fig.3) is previously uninvestigated cytologically. On the basis of this first exact chromosome number determination in the genus, 12 is suggested as its basic number.

All species of Rhamnaceae studied by us are uniformly based on $\mathrm{x}=12$. Most of the hitherto investigated taxa fall in line with this basic number. A few discordant chromosome records (cf. Darlington and Wylie, 1.c) need confirmation. Twelve seems to be the only or original basic number of this family. Polyploidy is infrequent in the family, eight of the nine presently studied species are diploid.

\section{Summary}

Cytological studies have been carried out in 21 woody species. The chromosome numbers of eighteen species have been presented for the first time. The basic numbers suggested for the three newly investigated genera are Lophopetalum $(x=20)$, Elaeodendron $(\mathrm{x}=17)$ and Berchemia $(\mathrm{x}=12)$. Polyploidy is frequent in Euonymus but rare or unrecorded in other Celastraceae and Rhamnaceae. The role of aneuploidy is significant in Celastraceae, but it appears to be lacking or meagre in Rhamnaceae which seems to have 12 as its original basic number.

\section{Acknowledgement}

The authors wish to express sincere thanks to the sponsoring authorities of the U.S. Government for financial assistance from the PL 480 funds in India (Grant A7-FS-12), given to Prof. P.N. Mehra.

\section{References}

Adatia, R. D. and Bavade, S. B. 1962. Embryology of the Celastraceae. "Plant Embryology, a symposium". 1-11. New Delhi.

Bowden, W. M. 1945. A list of chromosome numbers in higher plants II. Menispermaceae to Verbenaceae. Amer. J. Bot. 32: 191-201.

Darlington, C. D. and Wylie, A. P. 1955. Chromosome Atlas of Flowering Plants. London. 519.

Khoshoo, T. N. and Singh, N. 1963. Cytology of North-West Indian trees I. Zizyphus jujuba and $Z$. rotundifolia. Silvae Genetica 12: 158-174.

Mehra, P. N. and Khosla, P. K. 1969. In: IOPB chromosome numbers report. Taxon 18: 215-220.

- and Sareen, T. S. 1969. In: IOPB chromosome numbers report. Taxon 18: 439-441.

Morinaga, T., Mano, T. Maruyama, Y. and Yamazaki, Y. 1929. Chromosome numbers of cultivated plants II. Bot. Mag. Tokyo 43: 589-594.

Srinivasan, V. K. 1952. Chromosome numbers in the genus Zizyphus. Curr. Sci. 21: 224-225. 